Global Food History 1 (2015) [Bloomsbury Publishing]

\title{
Alcohol and Historiography in Early China
}

\author{
Author: \\ Roel Sterckx \\ Fellow, Clare College

\section{Address:} \\ Faculty of Asian and Middle Eastern Studies \\ University of Cambridge \\ Sidgwick Avenue \\ Cambridge CB3 9DA \\ United Kingdom \\ e-mail: rs10009@cam.ac.uk \\ tel. +441223335137
}

Joseph Needham Professor of Chinese History, Science, and Civilization

\begin{abstract}
:
This paper examines the moral ambiguity that surrounded alcohol consumption in early China and the ways in which the use and abuse of alcohol served as a measure to judge the past. Rule-guided drinking was part of social life, but, importantly, it was also a corner stone in sacrificial ritual and therefore an important measure to please the spirit world. In assessing the past, early Chinese writers often judged rulers and their regimes based on the way they handled alcohol and ritualized drinking. Moderation or excess in drinking was seen as a key indicator in a regime's health: bad and overindulgent rulers were pitched against sages, who were portrayed as masters in the art of moderate consumption. These judgements run as a red thread through the written record, from Zhou bronze inscriptions to Han memorials.
\end{abstract}

\section{Key words:}

Alcohol - historiography- ritual - early China 
Is not the way of the sage like a jug of wine set up in the middle of a crossroads? Those who pass by will pour some wine out, some take more, others less, in unequal amounts; but they all take what they think is appropriate. ${ }^{1}$

In the year $10 \mathrm{CE}$ Wang Mang's 王莽 (r. 9-23 CE) Superintendent of Agriculture, Lu Kuang 魯匡, submitted a memorial to the throne. In it he urged his ruler to set up a government monopoly on the production and distribution of alcoholic drink. The idea that the imperial court should control the production of alcohol or ban alcohol consumption during designated periods of time was not new. More than a century earlier, in $98 \mathrm{BCE}$, the Han court had implemented a similar monopoly, albeit one it found hard to successfully implement. Unlike the production of salt and iron, brewing turned out to be almost impossible to patrol and so the monopoly was abolished shortly afterwards following court debates in $81 \mathrm{BCE}^{2}$

There were precedents prior to the establishment of the Han when authorities sought to curb the use and abuse of alcohol. The state of Qin for instance had placed periodic restrictions on alcohol. Its statutes on agriculture uncovered at Shuihudi 睡虎地 (Yunmeng county, Hubei province; dating to $217 \mathrm{BCE}$ ) note that it was a crime for commoners living on farms to sell jiu 酒 “ale/wine". ${ }^{3}$ Furthermore, the text at the heart of what would later be referred to as the legalist doctrine that had shaped Qin, acknowledges the prospect of lucrative revenues that come with a monopoly on the sale of alcohol. 
According to the Book of Lord Shang (Shang jun shu 商君書), the legalist state was to impose heavy taxes on wine and meat:

If the prices of wine and meat are made high, and the taxes on them so heavy that they add up to ten times the cost of production, then merchants and retailers will be few, the farming populace will not be able to indulge in drinking bouts and officials will not overeat. If there are few merchants and retailers, then the ruler will not waste his grain; if people are unable to indulge in drinking bouts, agriculture will not be neglected; if officials do not overindulge, affairs of state will not be delayed and the ruler will not make mistakes in promoting people. If the ruler does not waste grain and if the people do not neglect agriculture, then it is certain that waste lands will be brought under cultivation. ${ }^{4}$

At times alcohol prohibitions were alleviated by the granting of drinking amnesties, also known as $p u$ 酺, as occurred in the late 180s BCE when emperor Han Wendi 文帝 gave permission to allow drinking gatherings for five days. Outside these periodic amnesties, Han law stipulated that those who gathered together in groups of three to drink "for no particular reason (wu gu 無故)" were subject to a fine. ${ }^{5}$ We have no way of knowing how lenient enforcers of the law were in judging what constituted a justified occasion for drinking.

Returning to Lu Kuang's memorial, however, it is clear that both ritual precept as well as the perceived moral conduct of those who drank were important markers. Indeed in his memorial $\mathrm{Lu}$ first emphasizes the vital role of wine in sacrificial ritual. He also 
points at its medical benefits and then goes on to argue that alcohol abuse had led to decadence in the past:

Wine is a beautiful gift of Heaven (天之美祿). It is the means whereby the rulers of old used to foster and nourish All under Heaven in sacrificial offerings and prayers for good fortune, and the means whereby they supported the physically weak and nourished the sick. Gatherings for the hundred rites would not take place without wine (非酒不行).

Lu Kuang then invokes two canonical texts that seemingly take opposing views on alcohol consumption, only to try and reconcile both positions:

Thus the Odes 詩 say: “If we are without wine, we buy some.” But the Analects 論 語 claim that "Confucius did not partake of wine bought [on the market]." These two citations do not contradict each other (二者非相反也). The Odes show evidence of an era of inherited peace, when the sale of wine was controlled by officials (酒酷在官), when wine was mild and excellent, convenient for all, and could easily be presented before one another. The Confucius of the Analects was active in a period that saw decline and disorder befall the Zhou, when wine sales were controlled (privately) by the people (酒酷在民), when the wine was poor, deficient, and adulterated; and therefore he mistrusted it and did not drink it. ${ }^{6}$ 
It is noteworthy how Lu Kuang's proposal to establish a government monopoly invokes alcohol consumption as a marker for judgement of the past and the moral conduct of individuals: when alcohol falls within the control of bureaucratic office (guan 官) it can be a substance for the good; however when handled by "the people" ( $\min$ 民) it creates trouble. Not only the consumption of alcohol, but also the purity and quality of the brews offered around the sacrificial altars and imbibed during banquets, it is claimed here, reflect the moral calibre of the times one lives in. At work here is the moral arbiter seeking to conciliate the ingestion of alcohol as a rule-guided and ritualised activity on the one hand, with drinking for pleasure on the other. By Wang Mang's time this idea that alcohol consumption was one among several significant indicators of the health of a regime and a barometer of the past appears to have been well embedded. Historical judgement was intricately intertwined with an assessment of how successive rulers and their officials handled alcohol: overindulgent rulers were pitched against sages, who were portrayed as masters in the art of moderate consumption. Such judgements run as a red thread through the written record, from Zhou bronze inscriptions to Han memorials such as the one mentioned above.

A drunken past

At the heart of Lu Kuang's memorial is a concern documented in China's historical record nearly as far back as the Shang (ca. $1200 \mathrm{BCE}$ ): namely, the idea that a substance that was indispensable to ensuring the efficacy of a sacrifice -- alcohol in the form of 
fermented grain liquors - at the same time, and when not properly managed, could tempt ordinary mortals to indulge in behavior that would obtain the opposite result of being abandoned by the spirit authorities altogether. "Getting the spirits drunk" (shen ju zui zhi 神具醉止), to paraphrase one piece preserved in the Odes (“Chu ci” 楚茨; “Thorny Caltrop"; Mao 209), could be a risky business for those participating in proceedings. ${ }^{7}$ This moral ambiguity of alcohol sparked comments on the character of individual rulers, their government as well as the epoch they represented.

The oldest layer of historical commentary sets the use and abuse of grain liquors in the context of ritual sacrifice. As early as Shang times, the pledging of wine, i.e. millet ale, was a routine element in ritual. A substantial number of Shang ritual bronzes were designed to heat or pour wine. Oracle bone inscriptions make reference to a feast or banquet offered to the spirits known as xiang 饗. ${ }^{8}$ Bronze inscriptions and sacrificial hymns from the succeeding Zhou period are replete with references to fragrant food and alcohol offered up to the spirits and consumed by ritual participants. Yet these texts also acknowledge the at times orgiastic atmosphere in which sacrificial events took place and warn of the dangers of excess. Alcohol was a central ingredient in ritual proceedings, yet it also challenged the physical and moral restraints imposed by ritual.

The association of alcohol with the moral decay of society is at the heart of the narrative of the demise of China's first historical dynasty, the Shang. An inscription cast on a bronze known as the "Da Yu ding" 大孟鼎, which records King Kang's 康王 (r.1005/3-978 BCE) appointment of a minister named Yu 孟 (in 981 BCE), praises King Wu's 武王 success in overthrowing the Shang. It hails the Zhou for their sobriety during ritual sacrifices: 
As to those serving in his administration, in serving wine they would not dare to get drunk, when assisting at the chai 紫 and zheng 丞 sacrifices, they would not dare to make merry ... We know that Yin [Shang] lost its Mandate because the feudatories of Yin and Yin's senior officers and princes all became lax through wine-drinking. ${ }^{9}$

A stark warning against overindulgence in drink also occurs in the "Mao Gong ding" 毛 公鼎, a late Western Zhou vessel recording instructions given by King Xuan 宣王 (r. 827/25-782 BCE) to his minister Mao Gong Cuo 毛公厝, and alcohol abuse is recorded in several other vessel inscriptions. ${ }^{10}$

It is in a text known as the "Jiu gao" 酒誥 (Pronouncement on Alcohol), one of twelve royal speeches preserved in the Shangshu 尚書 (Book of Documents), that we find what may be the oldest sustained criticism of the use of alcohol in Chinese history. Most scholars accept that the Pronouncement dates to the Western Zhou (1045-771 BCE). ${ }^{11}$ The text takes the form of a speech by King Cheng 成王 (r. 1042/35-1006 BCE), or, possibly, the Duke of Zhou 周公 (r. 1115-1108 BCE), to the king's younger brother, and it describes how the Shang perished when its last rulers succumbed to drinking. ${ }^{12}$ The first part of the speech reiterates the permissible uses of alcohol: alcohol should be used for important sacrificial offerings only; ${ }^{13}$ Heaven invariably punishes those who indulge in alcohol; people should drink only if and when they are presenting sacrifice; virtue therefore lies in sobriety. Only when one's duties to the elderly and the sovereign have been fulfilled should celebratory consumption of alcohol be permitted. In the second part 
of the address the founding kings of Shang are praised for their virtues while Zhou 紂, the last descendent of the once virtuous kings, is denounced for his excesses: "Wasted and inebriated, unwilling to stop and becoming ever more excessive, he [Zhou] took leave of his senses, not even death frightened him." Clouded by alcohol, King Zhou fails to offer "fragrant sacrifices whose scent of virtue would ascend to Heaven". Sacrificial scent is presented as a conduit for $d e$ 德 “virtue": “[the Shang] people flocked together in drunkenness, their stench was smelled on high." In sum, the house of Shang is said to have perished by the powers of alcohol. Wine, a later chapter in the Shangshu notes, destroyed the virtue of its founders, Heaven had sent down its wrath, and the Shang people committed the ultimate crime: they ate the animal victims destined for the spirits. ${ }^{14}$ The Pronouncement concludes with a pledge that the succeeding Zhou would monitor the intake of alcohol, arrest groups gathering to drink and give counsel to Shang ministers and officials who were addicted to alcohol. Thus establishing control over alcohol and the unbridled or unauthorized gathering of people was enshrined as a feat of good government which, in turn, was associated with the golden age of Zhou. By insisting that alcohol was to be consumed primarily in the context of sacrifice, the Pronouncement relegates the use of alcohol outside sacrifice to the realm of prohibition and taboo. It may be the first narrative in Chinese history that separates secular alcohol consumption from the sacrificial use of alcohol, condemning the former.

The Shang demise to alcohol became a stock image for moral and political decline in later Warring States $\left(5^{\text {th }}-2^{\text {nd }}\right.$ centuries BCE $)$ and Han $\left(2^{\text {nd }}\right.$ cent. BCE- $2^{\text {nd }}$ cent. CE) accounts of the past. It remains uncertain nevertheless to what extent the condemnation of alcohol in the Pronouncement reflected Shang ritual practice. The fact 
that the speech was composed at all makes it reasonable to assume that it was somehow responding to genuine circumstances on the ground. Likewise, the description of sacrificial wine as a sensory conduit of flavor and fragrance for the spirit world is plausible. Among Shang ritual bronzes, wine vessels take up a larger share than they do for Zhou, and archaeologists have therefore claimed that changes in bronze vessel culture reflect changing attitudes towards ritualized alcohol consumption. Jessica Rawson noted a shift in emphasis, around the early-ninth century BCE, from Shang style wine drinking vessels in favor of a new emphasis on food vessels that grew larger in form and numbers. ${ }^{15}$ This shift in the use of ritual vessels need not be directly linked with textual narratives in which Zhou castigates Shang's use of alcohol, but the parallel is interesting nevertheless. The textual picture of Shang and early Zhou ritual as being overly bibulous and orgiastic alongside a progressive soberness in vessel culture are plausible signs of changing attitudes toward the ritual use of food and drink from the mid-Western Zhou onward. Lothar von Falkenhausen argues that new food-centered rituals could indicate a greater emphasis on ritual formality, ritual purity, and an increasing desire to separate the sphere of ritual from daily life. Possibly communication with spirits by means of a drunken séance diminished in importance over time. ${ }^{16}$

While by late Western Zhou times alcohol may have been less significant as a sacrificial offering, it certainly continued to be consumed in a ritual setting. Zhou texts are full of evidence documenting alcohol consumption. For instance the fifth stanza in a piece entitled “Tang” 蕩 (“Mighty"; Mao 255) in the "Greater elegantiae" cycle in the Odes, highlights the charge against alcohol as part of the story of Zhou's emergence: 
King Wen, said "Come!

Come, you Yin and Shang!

Heaven did not flush you with wine.

Not good are the ways you follow;

Most disorderly are your manners.

Not heeding whether it is dawn or dusk

You shout and scream,

Turning day into night."

The Zhou conquest as a moral victory over drunkenness and debauchery becomes a topos in Warring States and Han texts. They repeatedly highlight the extravagant excesses of the last Shang king Zhou (i.e. Zhou Xin 紂辛) and his mirror persona, Jie Gui 桀癸, who allegedly caused the downfall of the preceding Xia. These kings hold court near a lake filled with wine, raise a mount from liquor dregs, dangle rashers of meat from poles and have naked boys and girls chase each other through it as if it were a forest. ${ }^{18}$ In the Mozi 墨子 spirits appear in a dream to King Wu and implore him to attack Shang "now that we have submerged King Zhou of Yin into the powers of alcohol."19 King Zhou, according to a fragment in the syncretist Shizi 尸子, "loved wine (to the point that he) forgot his own person and did no (longer) know how to employ worthies (好酒忘身, 不知用 賢). ${ }^{20}$ Only the Eastern Han critic Wang Chong 王充 (ca. 27-100 CE) goes out of his way to critique this vignette of the perpetually inebriated Shang king as a figment of historiographical imagination. Wang's diatribe is a rather pointless dismissal of traditional accounts of King Zhou's bibulous excesses focusing on where exactly his 
wine-lake might have been located at court. Yet the fact that Wang felt a need to home in on the question suggests that the theme of alcohol consumption touched a nerve in literati discourse of the past. ${ }^{21}$ In sum, these narratives that contrast the virtuous and sober Zhou against the inebriated last rulers of Shang inferred that the progression of history and humankind depended on a ruler's ability to keep the powers of alcohol at bay. Therefore if incompetent last rulers had their senses clouded by alcohol or were distracted by gustatory and physical pleasures, it was up to the founding kings of Shang and Zhou, assisted by cooks-turned-ministers such as Yi Yin 伊尹 and Lü Wang 吕望, to protect the royal house and safeguard their sovereign from overindulgence. ${ }^{22}$ While the demise of Shang receives a great deal of attention, it should be noted that the historiography of courts during the Springs-and-Autumns and Warring States periods is no less dotted with high officials and ministers given to drink. One notorious case is that of $\mathrm{Han} \mathrm{Hu}$ 罕虎 (cognomen $\mathrm{Zi} \mathrm{Pi}$ 子皮, d.529 BCE) in the state of Zheng 鄭, who dug himself an underground chamber where he would hide to drink the night away. ${ }^{23}$

As is already clear from the story of the demise of Shang, late Warring States and Han texts increasingly insist on the ideal of moderation and the principle that good rulers should be sober. This can be seen first and foremost in the emergence of narrative settings, often cast back in the past, in which a guardian figure or wise counsel dissuades his lord from having his judgments clouded by alcohol and reprimands him to stick to proper government. The figure of Yanzi 晏子 (Master Yan, Yan Ying 嬰) best illustrates this persona. Yanzi reminds his patron, Duke Jing of Qi 齊景公 (r.553-548 BCE) repeatedly of the virtues of moderation. On one occasion he tells his lord that in antiquity protocol required that all those who toasted more than five rounds would face execution. 
The aim of drinking, Yanzi insisted, was to capture each other's mood and get on with each other on a friendly basis. At no point, we are told, did the ancients' drinking detract from their duties. ${ }^{24}$

This insistence on moderation becomes a frequently recurring element in retrospective character descriptions of past sages and culture heroes. Politically inspired comments on the need for moderation in drinking, and eating, occur in nearly every late Warring States and early Han text that deals with the art of government. Unlike their wayward predecessors or superiors, sages are said to distinguish themselves through the art of moderation. The sage ruler gets through frequent and lengthy programs of ritual drinking without succumbing to excess. ${ }^{25}$ Not infrequently these comments play on the theme that in order to look after the body politic, people in power need to look after their bodies. "If a Son of Heaven becomes a habitual drinker," the Han Feizi 韓非子 contends, "he will lose the empire; if an ordinary person gets hooked on wine, he will lose his body/self." ${ }^{26}$ To no great surprise the Confucius figure topped the list of moderate consumers. ${ }^{27}$ But there were others too who stood out for their ability to handle ritual drinking and sensory pleasures without being detracted from governmental duties. The following passage depicts the Duke of Zhou:

When the Duke of Zhou governed the world, alcohol and meat were not removed from his presence, and the bells and drums (at his court) were not removed from their suspension (racks). (He) listened to music and (yet) the country was ordered; (but his own) labor had nothing to do with it. (He) drank alcohol and (still) worthies were promoted: (but his own) wisdom had nothing to do with it. (He) acted for 
himself and (yet) the people were enriched: (but his own) goodness had nothing to do with it. (For) he who knows the Way, crowds of worthies will serve for (him), and the stupid and wise will (all) completely manifest (their) true dispositions. ${ }^{28}$

Here effortless rule through delegating tasks and attracting talent to one's service allows a sage ruler to partake of alcohol and music and even to engage in some measure of personal wealth creation. Balance and moderation are presented as a safeguard for spontaneous rule.

The prevalence of this leitmotiv of the sober sage clearly irritated a critic such as Wang Chong who pours his scorn on Confucius' reputation as someone who could drink without limit: "King Wen 文王 drank one thousand zhong 鍾 measures of wine and Confucius one hundred goblets ( $g u$ 觙) $\quad \ldots$. They were alcohol addicts (酒徒), not sages. There is a method to the drinking of alcohol since the size of the chest and belly is almost equal among men ...". ${ }^{29}$

The sages also recognized the potential dangers of alcohol from the moment it was invented. Moral ambiguity is embedded in the origin narratives of alcohol. When Yi Di 義 (儀) 狄, the legendary inventor of ale, created his brew, the Huainanzi 淮南子 states, $\mathrm{Yu}$ 禹 the Great sampled it with appreciation but next removed his minister from office and issued a prohibition on alcohol to prevent excess. ${ }^{30} \mathrm{Yu}$ 's visionary prediction that wine would one day lead to the inevitable demise of some states is also incorporated in the following anecdote: 
The king of Liang 梁, Wei Ying 魏嬰, was hosting his feudal lords with a toast at Fantai 范臺. Feeling the pleasure of his wine, he called upon the ruler of Lu to raise the cup again. The ruler of $\mathrm{Lu}$ stood up, left his mat, and choosing his words carefully he said: "In ancient times the emperor's daughter ordered Yi Di to make wine and it was good. It was presented to Yu. Yu drank of it and found it pleasant. Thereupon he sent Yi Di away from him and issued an order banning wine, saying, 'Among later generations there will certainly be those who will lose their state because of this wine." ${ }^{\prime 31}$

That the pleasures brought on by alcohol inevitably imply political risk is also ingrained in the etymology of the graph jiu 酒 as proposed by Xu Shen's 許慎 (ca. 55-149 CE):

Jiu 酒 'alcohol' means jiu 就 'to achieve'. It is the means whereby the good and evil in human nature are achieved. The (graph) is composed of shui 水 and you 西, the latter also representing its phonetic. It also means zao 造 'to produce' and is the means whereby good and bad fortune are made to arise. In antiquity Yi Di invented (zuo 作) ale with dregs (unfiltered), Yu tasted it and found it excellent (but) following this he banned Yi Di. Du Kang 杜康 invented rice wine (shu jiu 柇酒). ${ }^{32}$

In sum, men of letters, masters of philosophy and those charged with interpreting history and judging its heroes and villains were keen to comment on the morality of drunkenness and the politics of alcohol as an ingredient in their assessment of the past and its paragons. 
Whereas in literary portrayals and poetry of early medieval China ( $3^{\text {rd }}$ cent. CE onwards), escapism, pleasure, temptation, stimulus and inspiration would become increasingly accommodated as positive virtues brought on by alcohol, the predominant assessments of the effects of alcohol in pre-imperial and early imperial times appear to hinge on moral ambiguity, social and ritual malfunction, and the inevitability of political decline. ${ }^{33}$

Ritual drinking

Above I noted that rituals and ritual sacrifice frequently provided the context for criticisms of excessive drinking and character judgment. The fragile boundaries between rule-guided drinking and uncontrolled excess are highlighted in several texts. The aforementioned ode "Chu ci" (Thorny Caltrop) presents a perfectly scripted scenario: the preparation and offering of sacrificial foodstuffs is followed by a banqueting scene performed as part of an ancestral ritual. Once the sacrifice is completed, an invocator announces that the spirits are satiated. Next the ritual participants go on to feast. ${ }^{34}$ Orderly sacrifices however could also descend into uncontrolled ritualized bedlam. Such are the scenes juxtaposed in “Bin zhi chu yan" 賓之初筵 ("When the guests first take to their seating mats"; Mao 220), another piece in the Odes, which the Mao preface places at the time of Duke Wu 武 of Wei 衛 (r. 812-758 BCE). It starts with two stanzas that describe the orderly and temperate use of alcohol during an archery ceremony and a concluding sacrifice. The archers are invited to take their seats and while host and guests toast each other with solemnity: 
The food-baskets and platters are arranged in rows,

With sauces and kernels displayed.

The wine is soft and good,

And all drink very peaceably.

Such orchestrated orderliness, the poem insists, befits the occasion of a sacrifice, when, sustained by music and dance, ancestral spirits are invited to bless their descendants:

When the guests first take their seats,

How decorous they are, how reverent!

While they are still sober

Their deportment is dignified and correct.

Next this picture of ritual perfection takes a turn. The following three stanzas then describe the intoxicated chaos that arises when ritual decorum is abandoned: guests start rioting, howling and brawling as the feast goes on and the wine keeps flowing. Those who fail to leave the scene when inebriated are said to "harm the virtue" ( $f a$ de 伐德) the proceedings are meant to instil: "Drinking wine is an occasion of great worth, only when a sense of deportment is preserved." 35 The final stanza then contains moralizing observations on the deficit of ritual occasion when drunkenness takes over and ritual specialists are called upon to supervise proceedings:

Whenever at these occasions wine is drunk; 
Some are tipsy, some are not.

So we appoint a master of ceremonies,

Sometimes assisted by a recorder.

"That drunk man is not behaving nicely;

He is making the sober feel uncomfortable.

Pray do not mention at random,

Things that do not belong together, that are quite silly.

What are not real words, do not say;

What leads nowhere, do not speak of,

Led on by drunkenness in your talk,

Bringing out "rams" (cups) and "hornless" (cups) side by side.

After three cups you don't know what you are saying;

What will become of you if you insist on taking more?! ${ }^{36}$

These poems illustrate that, despite the charge that alcohol had caused the fall of those that had ruled before them, the need to keep ritualized drinking within bounds remained high on the agenda for the Zhou nobility. ${ }^{37}$ The banquet was another such scene where the fine line between ritual reserve, formality and excess was easily transgressed. Drinking protocol during banquets or official missions could spark incidents that ranged from public humiliation to the assassination of political opponents. ${ }^{38}$

One of the most telling illustrations of the tension between ritual reverence and drinking for pleasure is preserved in an exchange, most likely apocryphal, between Confucius and his disciple Zigong 子貢 in the Liji 禮記 (Book of Rites). The story has 
Zigong returning from the New Year festival. This was an occasion which, one Han commentator notes, invariably led to bouts of drunkenness. Confucius asks his disciple whether he had derived any pleasure from the event, to which Zigong replied: "The people of the entire state behaved as if they were mad, I don't know yet wherein I should find pleasure." Confucius then comes to the defense of the celebrants and rebuts: "In exchange for the labor [they deliver] during an agricultural cycle that lasts a hundred days, they enjoy one day of plenty, this is what you do not understand. Even Kings Wen and Wu could not permanently stretch a bow or relax it and vice versa. To keep it now strung and now unstrung was the way of Wen and Wu. ${ }^{39}$ On this occasion Confucius seemingly accommodates unrestrained drinking to make a wider point to his disciple about a balance between duty and leisure. Yet Confucian ritual occasions were also criticized for offering a platform for bibulous behavior. Mozi vociferously condemns funerals. He claims that they are opportunities for overindulgence facilitated under the guise of ritual obligation. These rituals attract opportunistic beggars who "stuff food away like hamsters". People dash from funeral to funeral with their extended family to fill up:

As soon as the Five Grains have been gathered (i.e. during autumn and winter) they (i.e. Confucian ritualists) drag themselves along to large funerals and take their sons and grandsons with them so that they can get stuffed on drink and food. In the end they only need to be in charge of a number of funerals to have enough for their needs. They depend on other households for their wealth and the dignity they enjoy depends on the fields of others. When there is a funeral in a rich family 
they are overwhelmed with great joy saying: "This is our opportunity for clothing and food!",40

Even Confucius' alleged habit to be frugal in the presence of mourners provoked comments about the abuse of funerals as an occasion to stock up on free meat and wine. Unlike today, the argument went during court debates around $81 \mathrm{BCE}$, the ancients were exemplary members of society, always conscious of the fact that wine and meat should only be consumed in the context of sacrificial gatherings. ${ }^{41}$ The rules for ritualised drinking themselves, some claimed, were invented to control the excessive use of alcohol:

The rearing of pigs (to feast on grain-fed animals) and the making of wine (with the adjunct of drinking) were not intended to cause disaster. Yet when criminal charges and litigations grew increasingly in number, it was the result of excessive wine drinking. Therefore the kings of ancient times instituted rituals for wine drinking. With one toast, the host and the guests are obliged to salute each other numerous times. Thus one can drink for the whole day without becoming drunk. This is how the ancients prevented disasters caused by wine drinking. As such wine and food became a means whereby people were brought together in pleasure. ${ }^{42}$

These accounts however merely described an ideal, and evidence suggests that the politics of toasting were a real concern to some. For instance in a report among the aforementioned Qin legal documents found at Shuihudi, the refusal to participate in toasting at a village sacrifice is the subject of a legal complaint: 
When in my [the accused's] household there are sacrifices, we invite [the plaintiff] and the others, but [the plaintiff] and the others are unwilling to come; they also never invite me [the accused] to drink. When there are sacrifices in the village, I [the accused] together with the villagers as well as [the plaintiff] meet to drink and eat, but nobody is willing to share a cup or dish (with me). ${ }^{43}$

The politics of responding to an invitation to drink as well as the decision to reciprocate or refuse related directly to the ways in which local communities conceived of rank and hierarchy. Just as the handling of alcohol informed the judgement of character in the past, ritualised drinking prompted self-examination and tested one's relationship with fellow or rival, as well as with higher forces and powers beyond this world. The measured scene described below, where companions examine each other's character in an orderly gathering that is punctuated by proper decorum, sums up an idealized picture of conviviality at its best:

Friends and like-minded persons, Arrange their ceremonial tables and mats there,

Discuss the Way while feasting.

Setting the goblets adrift in a flowing stream,

Like running streams their cups overflow without stop;

Viands and sweetmeats are mixed in great profusion.

Some write poems, while others cap verses from the Classics, 
Each expounding his personal aspirations.

They examine each other in the light of the heritage of the Former Kings,

Rewarding the reverent,

Penalizing those found wanting a drink.

In accordance with the rules of this event,

Goblets are rinsed, wine cups refilled,

And the rhinoceros horn-goblets are raised in unison.

This drinking, however,

does not reach a state of drunkenness (yin bu zhi zui 飲不至醉);

The joy is not carried to wantonness;

Decorum is meticulously preserved;

Every movement is at one with the codes. ${ }^{44}$

\section{Conclusion}

It is likely that attempts by successive ruling houses in early China to control or monopolize the production, sale, and consumption of alcohol were partly motivated by economic concerns. It is also clear that the use and abuse of alcohol in early China was part and parcel of social and moral commentary. Drinking excesses were a continuous subject of criticism. Even the Han critic Wang Chong puts his brush to a memorial dubbed a "Prohibition on Alcohol” (“Jin jiu” 禁酒), in which he advises a local governor in Henan to curb alcohol use in order to put a halt to rampant crime in the area. ${ }^{45}$ Furthermore, alcohol prohibitions in antiquity would continue to invite comments among 
literati centuries later. ${ }^{46}$ But over and above issues such as the production and distribution of alcohol, or tax revenues drawn from alcohol, this essay has shown that the management of alcohol consumption also provided a powerful rhetorical tool to invoke or aggrandize the moral character and achievements of those in power. One could argue that when rulers in the early empires conceived of a ban on alcohol or wished to regulate its distribution and consumption through the agency of officials and ritual specialists, this was also a gesture that mimicked exemplary acts undertaken by rulers in an idealized past. If the ancient Zhou rulers were hailed in the Pronouncement for having washed away the wrongs of the past by banning drinking gatherings and stewarding their subjects through a program of ritualized drinking without excess, it is perhaps no surprise that many a ruler in succeeding centuries wished to be associated with similar measures, not in the least perhaps Wang Mang on whose watch the memorial we started this essay with was submitted. Even when, in reality, controlling ritual occasion or enforcing alcohol monopolies often turned out to end in failure, the ambition to do so provided a powerful label for the historiographer charged with rendering his protagonist fit for good government in his narrative. In the eyes of posterity, there were good reasons to turn down a drink.

Works cited 
Ariel, Yoav. K'ung-Ts'ung-Tzu. A Study and Translation of Chapters 15-23 with a Reconstruction of the Hsiao Erh-ya Dictionary. Leiden: E.J. Brill, 1996.

Chunqiu fanlu yi zheng 春秋繁露義證. Edited by Su Yu 蘇輿. Beijing: Zhonghua, 1996.

Chunqiu Zuozhuan zhu 春秋左傳注. Annotated by Yang Bojun 楊伯峻. Beijing: Zhonghua, 1995.

Da Dai Liji jiegu 大戴禮記解詁. Attributed to Dai De 戴德 (fl. ca. 72 BCE), edited by Wang Pinzhen 王聘珍. Beijing: Zhonghua, 1998.

Dobson, W.A.C.H. Early Archaic Chinese. Toronto: University of Toronto Press, 1962.

Er nian lüling yu Zouyan shu 二年律令與奏獻書. Edited by Wuhan daxue jianbo yanjiu zhongxin and Jingzhou bowuguan. Shanghai: Shanghai guji chubanshe, 2007.

Falkenhausen, Lothar von. "Late Western Zhou Taste." Études Chinoises 18, no.1 (1999): 143-78.

Falkenhausen, Lothar von. Chinese Society in the Age of Confucius (1000-250 BC). The Archaeological Evidence. Los Angeles: Cotsen Institute of Archaeology, University of California, 2006. 
Fayan 法言. Exemplary Figures. By Yang Xiong 揚雄 (53 BCE-18 CE). Translated and introduced by Michael Nylan. Seattle and London: University of Washington Press, 2013.

Fischer, Paul tr. Shizi. China's First Syncretist. New York: Columbia University Press, 2012.

Guoyu 國語. Shanghai: Guji chubanshe, 1978.

Han Feizi jishi 韓非子集釋. Attributed to Han Fei 韓非 (d. 233 BCE); annotated by Chen Qiyou 陳奇猷. Gaoxiong: Fuwen, 1991.

Han Shi waizhuan jishi 韓詩外傳集釋. Attributed to Han Ying 韓嬰 (fl. 150 BCE), annotated by Xu Weiyu 許維通. Beijing: Zhonghua, 1980.

Hanshu 漢書. Beijing: Zhonghua, 1962.

Huainanzi honglie jijie 淮南子鴻烈集解. Edited by Liu Wendian 劉文典. Taipei: Wenshizhe, 1992.

Hulsewé, Anthony F.P. Remnants of Ch'in Law. Leiden: E.J. Brill, 1985. 
Jinwen Shangshu kaozheng 今文尚書考証. Compiled by Pi Xirui 皮錫瑞 (1850-1908).

Beijing: Zhonghua, 1989.

Keightley, David N. “The Shang: China’s first historical dynasty” in Loewe, Michael and Edward Shaughnessy eds., The Cambridge History of Ancient China. From the Origins of Civilization to 221 BC (Cambridge: Cambridge University Press, 1999), 232-291.

Kern, Martin. 'Shi Jing Songs as Performance Texts: A Case Study of 'Chu ci' (Thorny Calthrop)," Early China 25 (2000): 49-111.

Kern, Martin. "Bronze Inscriptions, the Shijing and the Shangshu: The Evolution of the Ancestral Sacrifice during the Western Zhou," in Lagerwey. John and Marc Kalinowski eds., Early Chinese Religion. Part One: Shang Through Han (1250 $B C$ - $220 A D)($ Leiden: E.J. Brill, 2009), 143-200.

Knechtges, David R. “Gradually Entering the Realm of Delight: Food and Drink in Early Medieval China," in David R. Knechtges, Court Culture and Literature in Early China (Aldershot: Variorum, 2002), 229-39.

Kong Congzi 孔叢子. Attributed to Kong Fu 孔鮒 (Han). Congshu jicheng_edition. 
Li, Feng. Landscape and Power in Early China. The Crisis and Fall of the Western Zhou 1045-771 BC. Cambridge: Cambridge University Press. 2006.

Liji ijiie 禮記集解. Edited by Sun Xidan 孫希旦. Beijing: Zhonghua, 1995.

Loewe, Michael and Edward L. Shaughnessy (eds.). The Cambridge History of Ancient China. From the Origins of Civilization to 221 B.C. Cambridge and New York: Cambridge University Press, 1999.

Lüshi chunqiu jiaoshi 呂氏春秋校釋. Compiled under the auspices of Lü Buwei 呂不韋 (290-235 BCE). Annotated by Chen Qiyou 陳奇猷. Shanghai: Xuelin, 1995.

Lunheng jiaoshi 論衡校釋. Edited by Huang Hui 黃暉, with commentary by Liu Pansui 劉盼遂. Beijing: Zhonghua, 1990.

Mao shi zhengyi 毛詩正義. Annotated by Kong Yingda 孔穎達 (574-648 CE) et al. In Shisanjing zhushu, vol. 2.

Mozi jiangu 墨子閒詁. Edited by Sun Yirang 孫詒讓. Beijing: Zhonghua, 2001.

Poo Mu-chou. "The Use and Abuse of Wine in Ancient China." Journal of the Economic and Social History of the Orient 42, no.2 (1999): 123-51. 
Qin Yonglong 秦永龍. Xi Zhou jinwen xuanzhu 西周金文選注. Beijing: Shifan daxue, 1992.

Quan Han fu 全漢賦. Collated by Fei Zhengang 費振剛 et al. Beijing: Beijing daxue, 1997.

Rawson, Jessica. Western Zhou Ritual Bronzes in the Arthur M. Sackler Collections, vol.1. Cambridge, Mass.: Harvard University Press, 1990.

$R i$ zhi lu 日知祿 (Yuan chao ben 原抄本). By Gu Yanwu 顧炎武 (1613-1682). Taipei: Minglun chubanshe, 1970.

Shang jun shu zhuizhi 商君書錐指. Edited by Jiang Lihong 蔣禮鴻. Beijing: Zhonghua, 1996.

Shangshu da zhuan 尚書大傳. Attributed to Fu Sheng 伏勝 (fl. 250-175 BCE), commentary by Zheng Xuan 鄭玄 (127-200 CE), annotated by Chen Shouqi 陳壽 祺 (1771-1834). Congshu jicheng edition (Shanghai: Shangwu, 1935-40).

Shangshu zhengyi 尚書正義. Annotated by Kong Yingda 孔穎達 (574-648 CE) et al. In Shisanjing zhushu, vol. 1. 
Shiji 史記. Begun by Sima Tan 司馬談 (d. 112 BCE), primarily composed by Sima Qian 司馬遷 (ca. 145- ca. 86 BCE). Beijing: Zhonghua, 1959.

Shuihudi Qin mu zhujian 睡虎地秦墓竹簡. Edited by Shuihudi Qin mu zhujian zhengli xiaozu 整理小组. Beijing: Wenwu, 1991; rpt. 2001.

Shuowen jiezi zhu 說文解字注. Annotated by Duan Yucai 段玉裁 (1735-1815).

Shanghai: Shanghai guji, 1983.

Shuoyuan jiaozheng 說苑校證. Attributed to Liu Xiang 劉向 (79-8 BCE), annotated by Xiang Zonglu 向宗魯. Beijing: Zhonghua, 2000.

Sterckx, Roel. Food, Sacrifice, and Sagehood in Early China. New York: Cambridge University Press, 2011.

Waley, Arthur. The Book of Songs. New York: Grove Press, 1996.

Wu gao jie 五誥解. By Yang Jian 楊簡 (1141-1226 CE). Congshu jicheng edition.

Xinxu jiaoshi 新序校釋. Attributed to Liu Xiang, annotated by Shi Guangying 石光瑛 Beijing: Zhonghua, 2001. 
Yantie lun jiaozhu 鹽鐵論校注. Compiled by Huan Kuan 桓寬 (1st cent. BCE), annotated by Wang Liqi. Beijing: Zhonghua, 1996.

Yanzi chunqiu jishi 晏子春秋集釋. Annotated by Wu Zeyu 吳則虞. Beijing: Zhonghua, 1962.

Yue, Isaac and Siufu Tang eds. Scribes of Gastronomy. Representations of Food and Drink in Imperial Chinese Literature. Hong Kong: University of Hong Kong Press, 2013.

Zhanguo ce 戰國策. Compiled by Liu Xiang. Shanghai: Guji, 1995.

Zhouli zhengyi 周禮正義. Annotated by Sun Yirang 孫詒讓 (1848-1908). Beijing: Zhonghua, 1987.

\footnotetext{
${ }^{1}$ Huainanzi honglie jijie (Taipei: Wenshizhe, 1992), 10.319-20.

${ }^{2}$ Hanshu (Beijing: Zhonghua, 1962), 6.204. The rate of taxation on alcohol in 81 BCE, when the monopoly was discontinued, was two qian 錢 (bronze coins) per sheng 升 (a unit of 0.2 liter).

${ }^{3}$ Shuihudi Qin mu zhujian zhengli xiaozu, Shuihudi Qin mu zhujian (Beijing: Wenwu, 1991; rpt. 2001), 22 (slip 12); Anthony F.P. Hulsewé, Remnants of Ch'in Law (Leiden: E.J. Brill, 1985), 25 (A6). Jiu, which I translate "wine" in this essay, refers to fermented ales of various types. Jiu were brewed by using molded grains that could be combined with steamed rice and water and were then left to ferment.
} 
4 Shang jun shu zhuizhi (Beijing: Zhonghua, 1996), 1.12-13 (“Ken ling” 墾令). A date of ca. 359 BCE has been proposed for this chapter, that is, close to the time of Shang Yang 商鞅 (ca. 385-338 BCE) himself. “Drinking bout” translates han shi 酣迻 “to be intoxicated and blushingly red”.

5 Shiji (Beijing: Zhonghua, 1959), 10.417. The commentator Wen Ying 文穎 (fl. 196-220 CE) notes that fines could run up to four ounces of gold. See further Hanshu, 6.204 n.1. For other five-day drinking amnesties see e.g. Hanshu, 6.200, 7.229, 8.267.

${ }^{6}$ Hanshu, 24B.1182. The quotes are from “Fa mu” 伐木 (Mao 165) and Lunyu 10.8. There existed different views on what types of jiu were graded as superior and inferior. An “upper quality" (shang zun 上尊) grade is mentioned in the Hanshu (71.3051) where the commentator Ru Shun 如淳 $\left(3^{\text {rd }}\right.$ century CE) indicates that Han statutes ranked wine according to the types of grain that were fermented. Legal statutes recovered at Zhangjiashan 張家山 (present-day Nanjun in Hubei; dated to $186 \mathrm{BCE}$ ) use the same term and refer to lower-quality adulterated “mixed" wine as he jiu 和酒. See Er nian lüling yu Zouyan shu (Shanghai: Shanghai guji chubanshe, 2007), 214 (slip 302). The link between the purity of the wine one imbibes and one's degree of wisdom occurs in a Six Dynasties poem entitled "Rhapsody on Ale” (“Jiu fu” 酒賦), attributed retrospectively to the Western Han poet Zou Yang 鄒楊 (fl. ca. 154 BCE). It opens: “The clear (qing 青) makes wine/ The turbid (zhuo 濁) makes sweet brew/ The clear is wise and enlightened/ The turbid is dull and stupid." See David Knechtges, "Gradually Entering the Realm of Delight: Food and Drink in Early Medieval China," in David R. Knechtges, Court Culture and Literature in Early China (Aldershot: Variorum, 2002), 237. A similar link between morality and the purity and impurity of wine appears in a piece by Wang Can 王粲 (fl.177-217 CE); cf. Quan Han fu (Beijing: Beijing daxue, 1997), 670 ("Jiu fu").

${ }^{7}$ Mao shi zhengyi (Shisanjing zhushu ed.), 13B.4a-16a. For a detailed analysis of the structure of the poem, see Marin Kern, "Shi Jing Songs as Performance Texts: A Case Study of 'Chu ci' (Thorny Calthrop)," Early China 25 (2000): 49-111. The idea that spirits get drunk through sacrifice also occurs in a hymn for the suburban sacrifices of Han Wudi 武帝. See Hanshu, 25.1069. 
${ }^{8}$ David N. Keightley, “The Shang: China's first historical dynasty” in Loewe, Michael and Edward Shaughnessy eds., The Cambridge History of Ancient China. From the Origins of Civilization to 221 BC (Cambridge: Cambridge University Press, 1999), 258.

${ }^{9}$ For the inscription see Qin Yonglong 秦永龍, Xi Zhou jinwen xuanzhu 西周金文選注 (Beijing: Shifan daxue, 1992), 27-39; tr. W. Dobson, Early Archaic Chinese (Toronto: University of Toronto Press, 1962), 221-226. For a photograph of the vessel and a discussion of the royal gift it records see Loewe and Shaughnessy, The Cambridge History of Ancient China, 321; and Li Feng, Landscape and Power in Early China. The Crisis and Fall of the Western Zhou 1045-771 BC (Cambridge: Cambridge University Press, 2006), 127-28. The chai is a burnt offering, it has also been linked to mountain sacrifices. See e.g. Liji jijie (Beijing: Zhonghua, 1995), 34.904. The zheng is a grain sacrifice and one of four seasonal sacrifices offered in winter. See Guoyu (Shanghai: Guji, 1978), 3.153, 4.173, 5.208; Zhouli zhengyi (Beijing: Zhonghua, 1987), 3.1330; Liji jijie, 47.1249 (“Ji tong”).

${ }^{10}$ Dobson, Early Archaic Chinese, 219. Alcohol abuse is also recorded in the “Tian wang gui” 天亡筬 and the “Xiao yu ding” 小孟鼎 (early W. Zhou), which describes King Kang’s campaign against the Guifang 鬼方.

${ }^{11}$ Shaughnessy, "Western Zhou History," in Loewe and Shaughnessy eds, The Cambridge History of Ancient China, 294; and Poo Mu-chou, "The Use and Abuse of Wine in Ancient China." Journal of the Economic and Social History of the Orient 42, no.2 (1999): 129 (citing Guo Moruo). An early Western Zhou date for the royal speeches has been challenged recently. See Martin Kern, "Bronze Inscriptions, the Shijing and the Shangshu: The Evolution of the Ancestral Sacrifice during the Western Zhou," in Lagerwey, John and Marc Kalinowski eds., Early Chinese Religion. Part One: Shang Through Han (1250 BC- 220 $A D)($ Leiden: E.J. Brill, 2009), 183-188. Kern dates them to the mid- to late Western Zhou and argues that they are commemorative in nature. Hanshu, 30.1706 notes that the "Jiu gao" chapter was missing slips and Yang Xiong 揚雄 (53 BCE-18 CE) flags up that it came to have "unexpected gaps" in it. See Yang Xiong, Exemplary Figures (Fayan), translated by Michael Nylan (Seattle and London: University of Washington Press, 2013), 73-75 (5.8). 
${ }^{12}$ Shangshu zhengyi (Shisanjing zhushu ed.), 14.14a-24a; Jinwen Shangshu kaozheng (Beijing: Zhonghua, 1989), 15.321-327.

${ }^{13}$ Yang Jian 楊簡 (1141-1226 CE) comments that in antiquity wine was not used in small sacrifices. See Wu gao jie (Congshu jicheng ed.), 2.26.

${ }^{14}$ Shangshu zhengyi, 10.14b-16b (“Weizi”微子); Jinwen Shangshu kaozheng, 9.227-229. See also Shangshu dazhuan (Congshu jicheng ed.), 4.25 (“Yin zhuan” 殷傳). The “Weizi” chapter could be as late as the Warring States period. For further reference to the demise of Shang to alcohol see Shangshu zhengyi, 16.14b (“Wu yi” 無遺).

${ }^{15}$ On the ritual reforms in the mid-Western Zhou and the shift away from the use of drinking vessels see Jessica Rawson, Western Zhou Ritual Bronzes in the Arthur M. Sackler Collections, vol.1. (Cambridge, Mass.: Harvard University Press, 1990), 102-10; and Rawson, "Western Zhou Archaeology" in Loewe and Shaughnessy eds., The Cambridge History of Ancient China, 360, 435.

${ }^{16}$ Lothar von Falkenhausen, “Late Western Zhou Taste.” Études Chinoises 18, no.1 (1999): 152-153; and von Falkenhausen, Chinese Society in the Age of Confucius (1000-250 BC). The Archaeological Evidence (Los Angeles: Cotsen Institute of Archaeology, University of California, 2006), 49.

${ }^{17}$ Mao shi zhengyi, 18A.5a; tr. Arthur Waley, The Book of Songs (New York: Grove Press 1996), 262.

${ }^{18}$ Lüshi chunqiu jiaoshi (Shanghai: Xuelin, 1995), 23.1559 (“Guo li”); Shiji, 3.105, 38.1607; Huainanzi, 8.256 ("Ben jing”); Chunqiu fanlu (Beijing: Zhonghua, 1996), 4.106 ("Wang dao"); Han Shi waizhuan (Beijing: Zhonghua, 1980), 2.57 (II.2), 4.130 (IV.2); Xinxu jiaoshi (Beijing: Zhonghua, 2001), 6.180 (“'Ci che”刺奢); Shuoyuan (Beijing: Zhonghua, 2000), 10.257 (“Jing shen”敬慎); Da Dai Liji (Beijing: Zhonghua, 1998), 11.218 ("Shao xian").

${ }^{19}$ Mozi jiangu (Beijing: Zhonghua, 2000), 5.152 (“Fei gong, xia” 非攻下).

${ }^{20}$ Paul Fischer, Shizi. China's First Syncretist (New York: Columbia University Press, 2012), 131 (fragment 38).

${ }^{21}$ Lunheng jiaoshi (Beijing: Zhonghua, 1990), 7.341-42, 348-50 (“Yu zeng” 語增).

${ }^{22}$ For a more detailed discussion of stewards, cooks and butchers as sage advisers see Roel Sterckx, Food, Sacrifice, and Sagehood in early China (New York: Cambridge University Press, 2011), 49-76. 
${ }^{23}$ Chunqiu Zuozhuan zhu (Beijing: Zhonghua, 1995), 1175 (Lord Xiang, year 30).

${ }^{24}$ Cf. the stories in Yanzi chunqiu jishi (Beijing: Zhonghua, 1962), 1.9-23.

${ }^{25}$ Shuoyuan, 19.507-508 (“Xiu wen”).

${ }^{26}$ Han Feizi jishi (Gaoxiong: Fuwen, 1991), 7.430 (“Shui lin, shang”).

${ }^{27}$ See Sterckx, Food, Sacrifice and Sagehood, 42-48.

${ }^{28}$ Fischer, Shizi, 78 (“Fen” 分).

${ }^{29}$ Lunheng jiaoshi, 7.346 ("Yu zeng”).

${ }^{30}$ Huainanzi, 20.694 (“Tai zu”). For Yi Di as inventor of ale, see Huainanzi, 19.646 (“Xiu wu”); Shuowen jiezi (Shanghai: Shanghai guji, 1983), 14B.34a; and Lunheng jiaoshi, 30.1194 (“Zi ji”).

${ }^{31}$ Zhanguo ce (Shanghai: Guji, 1995), 23.846-47.

${ }^{32}$ Shuowen jiezi, 14B.33b-34a.

${ }^{33}$ For more on the evolving perceptions of alcohol in medieval literature and beyond see the essays in Isaac Yue and Siufu Tang eds., Scribes of Gastronomy. Representations of Food and Drink in Imperial Chinese Literature (Hong Kong: University of Hong Kong Press, 2013), especially chapter three by Nicholas Morrow Williams ("The Morality of Drunkenness in Chinese Literature of the Third Century CE”).

${ }^{34}$ Mao shi zhengyi, 13B.4a-16a.

${ }^{35}$ The link between alcohol and $d e$ 德 “virtue, power" is also made in the opening stanza of “Ji zui”" 既醉 (Mao 247). See Mao shi zhengyi, 17B.8b. The link between satiation and good fortune is made in "Zhi jing" 執競 (Mao 274). See Mao shi zhengyi, 19B.10a.

${ }^{36}$ Mao shi zhengyi, 14C.1b-15b; tr. Waley, The Book of Songs, 207-209 (modified).

${ }^{37}$ For criticisms of drinking see further "Yi" 抑 (Mao 256; stanza 3). Other poems describing wine libations and offerings include “Xin nan shan” 信南山 (Mao 210), “Feng nian” 豐年 (Mao 279), “Zai shan” 載芝 (Mao 290), “Wen Wang” 文王 (Mao 235), “Han lu” 漢麓 (Mao 239), “Bi gong”閂宮 (Mao 300), and “Lie zu” 列祖 (Mao 302).

${ }^{38}$ For examples, see Sterckx, Food, Sacrifice and Sagehood, 38-42. 
${ }^{39}$ Liji jijie, 42.1115 ("Za ji”). According to the Zhouli, the control on the sale and use of wine consumed during festivals fell within the province of the pingshi 苹氏 “river patroller”. See Zhouli zhengyi, 70.29052907. For the New Year festival as a bibulous break from a season of hard labor, see also Hanshu, 66.2896. ${ }^{40}$ Mozi jiangu, 9.291-93 (“Fei Ru, xia” 非儒下).

${ }^{41}$ Yantie lun jiaozhu (Beijing: Zhonghua, 1996), 6.351, 6.353 (“San bu zu”).

${ }^{42}$ Liji jijie, 37.997 (“Yue ji”). See also Shiji, 24.1199.

${ }^{43}$ Shuihudi Qin mu zhujian, 162-163 (slips 92-93); Hulsewé, Remnants of Ch'in Law, 206 (E24).

${ }^{44}$ Kong Congzi (Congshu jicheng ed.), 3.153 (“Rhapsody on the Willow”; “Yang liu fu” 楊柳賦); tr. Yoav Ariel, K'ung-Ts'ung-Tzu. A Study and Translation of Chapters 15-23 with a Reconstruction of the Hsiao Erh-ya Dictionary (Leiden: E.J. Brill, 1996), 102-103.

${ }^{45}$ Lunheng jiaoshi, 29.1182 (“Dui zuo” 對作).

${ }^{46}$ For instance, in his Ri zhi lu 日知錄, Gu Yanwu 顧炎武 (1613-1682) collates historical references to the banning of wine sales or wine consumption. For the early period he singles out the "Jiu gao", two decrees issued by Emperor Jing 景, and one by Emperor Xuan 宣. See Ri zhi lu, 238 (“Jin jiu”禁酒). 